Case Reports in
Gastroenterology
Case Rep Gastroenterol 2021;15:115-122

DOI: 10.1159/000509494

Published online: February 3, 2021

(C) 2021 The Author(s)

Published by S. Karger AG, Basel

www.karger.com/crg

This article is licensed under the Creative Commons Attribution-NonCommercial 4.0 International License (CC BY-NC) (http://www.karger.com/Services/OpenAccessLicense). Usage and distribution for commercial purposes requires written permission.

\title{
Hepatitis E Viral Association with Autoimmune Hepatitis: A Viral Trigger or Cross-Reactivity
}

\author{
Khaled A. Elfert ${ }^{a} \quad$ Hana Mahmoud Qasim ${ }^{a} \quad$ Mohanad M. Faisal $^{a}$ \\ Aya Elghazali $^{b} \quad$ Mohammed Y.A. Siddiqui $^{a} \quad$ Mahir Petkar $^{c}$ \\ Nagham Sadik ${ }^{a}$ \\ a Department of Medicine, Hamad Medical Corporation, Doha, Qatar; ${ }^{\mathrm{b}}$ The National Ribat \\ University, Khartoum, Sudan; 'Department of Laboratory Medicine and Pathology, \\ Histopathology Section, Hamad Medical Corporation, Doha, Qatar
}

\section{Keywords}

Autoimmune hepatitis · Hepatitis E virus · Viral trigger · Cross-reactivity

\begin{abstract}
Autoimmune hepatitis $(\mathrm{AlH})$ is a chronic disease characterized by hepatocellular inflammation and destruction. Its pathogenesis remains unclear. Current evidence suggests that environmental factors, including viral infections, are implicated as possible triggers. We present a case of a 36-year-old lady with systemic lupus erythematosus who presented with abdominal pain, nausea, vomiting, and jaundice. She was initially diagnosed as acute hepatitis E virus (HEV) infection based on positive serology, but she did not improve with conservative management. Subsequently, she underwent liver biopsy that showed features characteristic of $\mathrm{AlH}$. We discuss the role of HEV as a possible trigger of $\mathrm{AlH}$. We also highlight the possibility of crossreactivity between liver antigens and HEV as an explanation for the positive HEV serology in $\mathrm{AlH}$. We explore the management options of cases in which both acute HEV infection and $\mathrm{AlH}$ coexist, which might be challenging as there is no current consensus whether to start
\end{abstract}

Hana Mahmoud Qasim
Internal Medicine Department, Hamad Medical Corporation
Hamad General Hospital, Ahamd bin Ali St.
Doha 00000 (Qatar)
hanaa.qasem1@gmail.com




\section{Case Reports in Gastroenterology}

Case Rep Gastroenterol 2021;15:115-122

DOI: $10.1159 / 000509494$

(c) 2021 The Author(s). Published by S. Karger AG, Basel www.karger.com/crg

Elfert et al.: Hepatitis E Viral Association with Autoimmune Hepatitis: A Viral Trigger or Cross-Reactivity

immunosuppressive therapy or to manage such cases conservatively. Moreover, we discuss previous similar cases in which different lines of management were chosen.

(C) 2021 The Author(s)

Published by S. Karger AG, Basel

\section{Introduction}

Hepatitis E virus (HEV) is a single-stranded RNA virus that typically causes acute viral hepatitis. The infection is usually self-limited. The clinical manifestations include jaundice, malaise, anorexia, fever, and abdominal pain. The management of the acute infection is supportive in most of the cases. Chronic infection can occur in the immunocompromised population, such as organ transplant recipients and hematological malignancies patients. The treatment in this subgroup is to reduce the dose of immunosuppressives and/or initiate antiviral therapy [1].

Autoimmune hepatitis (AIH) is an immune-mediated liver disease characterized by hypergammaglobulinemia and circulating antibodies. It predominantly affects females, and it can occur at any age. The diagnosis of AIH depends on the presence of characteristic signs and symptoms, in addition to certain laboratory, serological, and histological findings. The clinical presentation ranges from being asymptomatic to acute liver failure. The clinical manifestations include nonspecific symptoms, such as nausea, anorexia, fatigue, abdominal pain, and itching. Clinical examination might reveal hepatomegaly. The laboratory findings include a rise in liver transaminases that is more common than the rise in alkaline phosphatase and bilirubin. One of the characteristic laboratory findings is raised serum globulins, such as immunoglobulin G (IgG). Circulating antibodies commonly present in AIH include antinuclear antibody (ANA), smooth muscle antibody (SMA), antibody to liver/kidney microsomal type 1 (anti-LKM1), and anti-liver cytosol type 1 (anti-LC1). Exclusion of other etiologies that can cause chronic hepatitis is also required to establish the diagnosis. In addition, AIH is commonly associated with other autoimmune diseases. The presentation of AIH can be acute and severe and might mimic viral or toxic hepatitis [2, 3].

It is hypothesized that it happens when a genetically predisposed patient is exposed to an environmental trigger [2]. This hypothesis is supported by the finding of molecular mimicry between viral epitopes and liver antigens. However, identifying the environmental trigger can be challenging given the fact that the process of induction might occur years before the clinical manifestation of the disease [3]. Environmental triggers implicated in the development of AIH include viruses, drugs, and immunization. Examples of the viruses are hepatitis A virus, hepatitis $C$ virus, Epstein-Barr virus, herpes simplex virus type 1, and cytomegalovirus [4-6].

The increased seroprevalence of AIH-related autoantibodies in patients with HEV [7] and the increased prevalence of HEV serology in patients with AIH [5] raise the possibility of an association between the two diseases. Here, we report a case of a female patient with a history of systemic lupus erythematosus (SLE) who was diagnosed with an acute HEV infection based on positive serology, and later the liver biopsy showed AIH.

\section{Karger'=}




\section{Case Reports in Gastroenterology}

\begin{tabular}{l|l}
\hline Case Rep Gastroenterol 2021;15:115-122 \\
\hline DOI: 10.1159/000509494 & $\begin{array}{l}\text { @ 2021 The Author(s). Published by S. Karger AG, Basel } \\
\text { www.karger.com/crg }\end{array}$
\end{tabular}

Elfert et al.: Hepatitis E Viral Association with Autoimmune Hepatitis: A Viral Trigger or Cross-Reactivity

\section{Case Report/Case Presentation}

We report a 36-year-old Lebanese woman who presented to our hospital with a 12-day history of upper abdominal pain, anorexia, nausea, and vomiting. It was associated with joint pain and swelling, mostly in the small joints of the fingers. Also, she reported yellowish skin discoloration and skin rash on the chest during the same period. She had a past medical history of SLE, diagnosed at the age of 18 years. Her SLE diagnosis was based on the presence of arthritis and malar rash with positive autoantibodies, such as ANA and anti-double stranded DNA antibody (anti-dsDNA). Four months prior to her presentation, her ANA and anti-dsDNA titers were $1: 1,240$ and $25.00 \mathrm{IU} / \mathrm{mL}$, respectively. She was stable on maintenance therapy with hydroxychloroquine $400 \mathrm{mg}$. She had a history of autoimmune Hashimoto's thyroiditis and was treated with levothyroxine $125 \mu \mathrm{g}$. Besides that, she was treated for latent tuberculosis in the past with 4 months of rifampicin. She underwent gastric plication in 2018. She denied taking any other medications. She is an occasional alcohol consumer; her last drink was 2 weeks prior to presentation.

On examination, she was conscious, alert, and vitally stable. Her general examination also revealed jaundice and petechial rash on the upper chest with joint swelling and tenderness mostly at the metacarpophalangeal joints of both hands with no flapping tremor. Abdominal examination revealed tenderness in the epigastric area. She had tender hepatomegaly. No ascites or splenomegaly could be identified.

Her laboratory findings upon admission revealed deranged liver function tests, as shown in Table 1. The patient had positive hepatitis E IgM antibody, while hepatitis E IgG antibody and HEV polymerase chain reaction were negative. Her other hepatitis viral serology, including hepatitis A virus, hepatitis B virus, and hepatitis C virus, were negative. Epstein-Barr virus and cytomegalovirus serology were negative. Toxicology screening was negative for acetaminophen and ethanol. Her ANA titer was 1:640 with homogenous pattern, anti-dsDNA titer was $26.00 \mathrm{IU} / \mathrm{mL}$, and total IgG level was $16.09 \mathrm{gm} / \mathrm{L}$ (7.00-16.00). She had negative antiSmith (anti-Sm) antibodies, antimitochondrial antibodies (AMA), and anti-LKM. Her ultrasound and magnetic resonance imaging of the liver showed average-sized liver with homogenous echotexture and subhepatic collection (Fig. 1). Doppler ultrasound of the liver showed patent hepatic veins. In the presence of a history of latent tuberculosis and previous abdominal surgery, ultrasound-guided aspiration of the subhepatic collection was done. The fluid analysis showed a white blood cells count of $1,375 / \mu \mathrm{L}$ with $87 \%$ lymphocytes, red blood cells of $6,625 / \mu \mathrm{L}$, bilirubin of $192 \mu \mathrm{mol} / \mathrm{L}$, and negative bacterial and mycobacterial cultures. The impression was that the subhepatic fluid was a reaction to the hepatic inflammatory process.

As the patient was not clinically improving after 1 week of conservative management and her liver function tests were not trending down, liver biopsy was performed. The liver biopsy showed moderate lobular and portal tract inflammation (Fig. 2, 3). The inflammation in the portal tracts contained a significant number of plasma cells (Fig. 4), apart from many lymphocytes. Occasional plasma cells were also noted within the lobules. Lobular disarray was present, and acidophil bodies were easily identifiable. Overall, the histological appearances were compatible with a diagnosis of AIH.

\section{Karger'=}




\section{Case Reports in Gastroenterology}

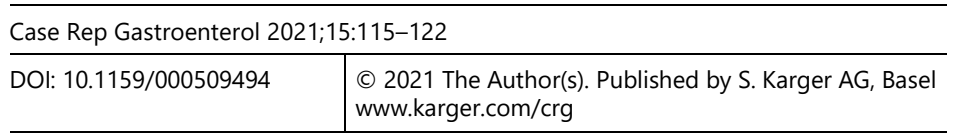

Elfert et al.: Hepatitis E Viral Association with Autoimmune Hepatitis: A Viral Trigger or Cross-Reactivity

Using the revised AIH scoring system [8], our patient's score was 23, which indicated a definite diagnosis of AIH. She was commenced on prednisolone $30 \mathrm{mg}$ and azathioprine 50 mg once daily, which was increased 10 days later to $100 \mathrm{mg}$. Her subsequent follow-up after 3 weeks showed dramatic clinical and laboratory improvement. Six weeks later, her liver function tests normalized (Table 1). She was maintained on azathioprine $100 \mathrm{mg}$ once daily with a tapering dose of prednisolone. Five months after the initial presentation, she had AIH relapse (Table 1). Repeated HEV serology at that time was negative for both IgM and IgG. She continued taking prednisolone and azathioprine with good clinical response.

\section{Discussion}

We reviewed the literature to look for cases in which acute HEV infection and AIH coexisted. In 2 of these cases, the patients were treated conservatively $[9,10]$. In a third case, the patient was started on immunosuppressive therapy which was later stopped after the patient was found to have positive HEV IgM antibodies and polymerase chain reaction [11]. Followup for these cases showed improvement in liver function parameters. Conservative treatment was recommended because of the uncertainty of the benefit of immunosuppressives in such cases and given that the diagnosis of AIH was probable according to the revised AIH scoring system [8] in these 2 cases $[9,10]$. It is interesting that, in the above studies, the autoimmune markers became negative during the follow-up period. This would suggest that positive autoimmune markers were a manifestation of the disease rather than a surrogate marker of autoimmune disease, as supported by a cross-sectional study by Terziroli Beretta-Piccoli et al. [7]. In this study, 48 patients with acute HEV infection were tested for AIH-related autoantibodies, such as ANA and anti-smooth muscle antibodies (ASMA). Fifty percent of the studied subjects had at least 1 autoantibody present.

In other case reports of concomitant HEV infection and $\mathrm{AIH}$, the patients were started on treatment for AIH with steroids (with or without other immunosuppressive medications), with satisfactory response to treatment and without prolongation of the duration of viremia $[12,13]$. In this group, the HEV was considered a trigger for the autoimmune disease. A number of studies have explored the possibility of HEV being a primary trigger for AIH [5, 14]. Pischke et al. [5], for example, reported that the seroprevalence of HEV was higher in AIH patients compared to both healthy individuals and patients with chronic viral hepatitis. Three of the AIH patients who had a positive HEV serology had HEV-specific T-cell responses confirming that they had contact with HEV. The same study showed that the AIH patients with HEV seropositivity did not have a worse outcome with immunosuppressive treatment compared to AIH patients who had negative serology. Additionally, Le Cann et al. [15] also reported a high prevalence of HEV-positive serology in AIH patients in comparison to primary biliary cirrhosis patients.

In our patient, we assumed that HEV was the trigger for the AIH. We decided to start immunosuppressive treatment as the diagnosis of AIH was definite and the liver function tests were not improving after 2 weeks of conservative treatment, and more so considering the

\section{Karger'=}




\section{Case Reports in Gastroenterology}

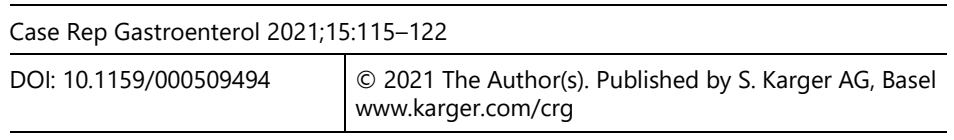

Elfert et al.: Hepatitis E Viral Association with Autoimmune Hepatitis: A Viral Trigger or Cross-Reactivity

presence of another autoimmune disease (similar to the case published by Thodou et al. [12]). Our patient showed an overall good response to treatment.

Llovet et al. [16] postulated an explanation for the presence of positive serology of HEV in patients with AIH. In their cross-sectional study, they demonstrated that there are more HEV IgG antibodies present in the acute AIH group than in the chronic AIH and the acute nonAIH groups. Moreover, they reported a positive correlation between the presence of anti-HEV IgG and higher IgG levels and autoantibodies titers. They concluded that the positive serology for HEV could be explained by the false positivity which is attributed to the cross-reactivity between liver autoantigens and HEV $[5,16]$. We think that this might be the case in our patient given that her only positive HEV serology in the initial presentation was IgM, and all HEV serological tests became negative during the follow-up period. However, it is worth noting that in the study suggesting a correlation between immunoglobulin level and HEV serology the positive HEV serology was for IgG, not IgM, unlike our case.

From the above-mentioned review, we think acute HEV infection may trigger transient features of $\mathrm{AIH}$, including positive autoantibodies or histopathological evidence, which may persist and necessitate treatment as genuine AIH in a proportion of the patients. The possibility of false positivity of HEV serology in AIH should also be considered.

\section{Acknowledgment}

We acknowledge Dr. Mohammed Danjuma for his scientific support, Dr. Shaikha Al-Shokri for manuscript review, Dr. Ahmed Emad Mahfouz for reporting the diagnostic images, and the Internal Medicine Residency Program, Hamad Medical Corporation, for scientific support.

\section{Statement of Ethics}

The patient gave her written informed consent to publish her case (including publication of images).

\section{Conflict of Interest Statement}

All authors have no conflicts of interest.

\section{Funding Sources}

Self-funding.

\section{Karger'=}




\section{Case Reports in Gastroenterology}

\section{Author Contributions}

Khaled A. Elfert: manuscript writing, literature review. Hana Qasim: corresponding author, manuscript writing, literature review. Mohanad M. Faisal: manuscript writing, literature review. Aya Elghazali: manuscript writing, literature review. Mohammed Y.A. Siddiqui: manuscript review, literature review. Mahir Petkar: histopathology slides examination and reporting. Nagham Sadik: team supervisor and mentor, manuscript review.

\section{References}

1 Kamar N, Dalton HR, Abravanel F, Izopet J. Hepatitis E virus infection. Clin Microbiol Rev. 2014;27:116-38.

2 Manns MP, Czaja AJ, Gorham JD, Krawitt EL, Mieli-Vergani G, Vergani D, et al. AASLD Practice Guidelines. Diagnosis and Management of Autoimmune Hepatitis. Hepatology. 2010;51(6):2193-2213.

3 Krawitt EL. Autoimmune hepatitis. N Engl J Med. 2006;354:54-66.

4 Zachou K, Muratori P, Koukoulis GK, Granito A, Gatselis N, Fabbri A, et al. Review article: Autoimmune hepatitis - Current management and challenges. Aliment Pharmacol Ther. 2013 Oct;38(8):887-913.

5 Pischke S, Gisa A, Suneetha PV, Wiegand SB, Taubert R, Schlue J, et al. Increased HEV Seroprevalence in Patients with Autoimmune Hepatitis. PLoS One. 2014 Jan;9(1):e85330.

6 Vento S, Cainelli F. Is there a role for viruses in triggering autoimmune hepatitis? Autoimmun Rev. 2004 Jan;3(1):61-9.

7 Terziroli Beretta-Piccoli B, Ripellino P, Gobbi C, Cerny A, Baserga A, Di Bartolomeo C, et al.; Swiss Autoimmune Hepatitis Cohort Study Group. Autoimmune liver disease serology in acute hepatitis E virus infection. J Autoimmun. 2018 Nov;94:1-6.

8 Alvarez F, Berg PA, Bianchi FB, Bianchi L, Burroughs AK, Cancado EL, et al. International Autoimmune Hepatitis Group Report: review of criteria for diagnosis of autoimmune hepatitis. J Hepatol. 1999 Nov;31(5):929-38.

9 Nagasaki F, Ueno Y, Kanno N, Okamoto H, Shimosegawa T. A case of acute hepatitis with positive autoantibodies who actually had hepatitis E virus infection. Hepatol Res. 2005 Jun;32(2):134-7.

10 Patel I, Ching Companioni R, Bansal R, Vyas N, Catalano C, Aron J, et al. Acute hepatitis E presenting with clinical feature of autoimmune hepatitis. J Community Hosp Intern Med Perspect. 2016 Dec;6(6):33342.

11 Vieira CL, Baldaia C, Fatela N, Ramalho F, Cardoso C. Case of acute hepatitis E with concomitant signs of autoimmunity. World J Hepatol. 2013 Mar;5(3):152-5.

12 Thodou V, Buechter M, Manka P, Gerken G, Kahraman A. Course of hepatitis E infection in a patient with rheumatoid arthritis and autoimmune hepatitis: A case report. Medicine (Baltimore). 2017 Dec;96(51):e9407.

13 Valenzuela V, Pinto JI, Padilla M, Piscoya A, De Los Rios R, Surco Y, et al. [Severe decompensation of hepatitis E in a patient with autoimmune hepatitis: a case report]. Rev Gastroenterol Peru. 2012;32(2):187-91.

14 van Gerven NM, van der Eijk AA, Pas SD, Zaaijer HL, de Boer YS, Witte BI, et al.; Dutch Autoimmune Hepatitis Study Group. Seroprevalence of hepatitis E Virus in autoimmune hepatitis patients in the Netherlands. J Gastrointestin Liver Dis. 2016 Mar;25(1):9-13.

15 Le Cann P, Tong MJ, Werneke J, Coursaget P. Detection of antibodies to hepatitis E virus in patients with autoimmune chronic active hepatitis and primary biliary cirrhosis. Scand J Gastroenterol. 1997 Apr;32(4):387-9.

16 Llovet LP, Gratacós-Ginés J, Ortiz 0, Rodriguez-Tajes S, Lens S, Reverter E, et al. Higher seroprevalence of hepatitis E virus in autoimmune hepatitis: role of false-positive antibodies. Liver Int. 2020 Mar;40(3):55864. 


\section{Case Reports in Gastroenterology}

Case Rep Gastroenterol 2021;15:115-122
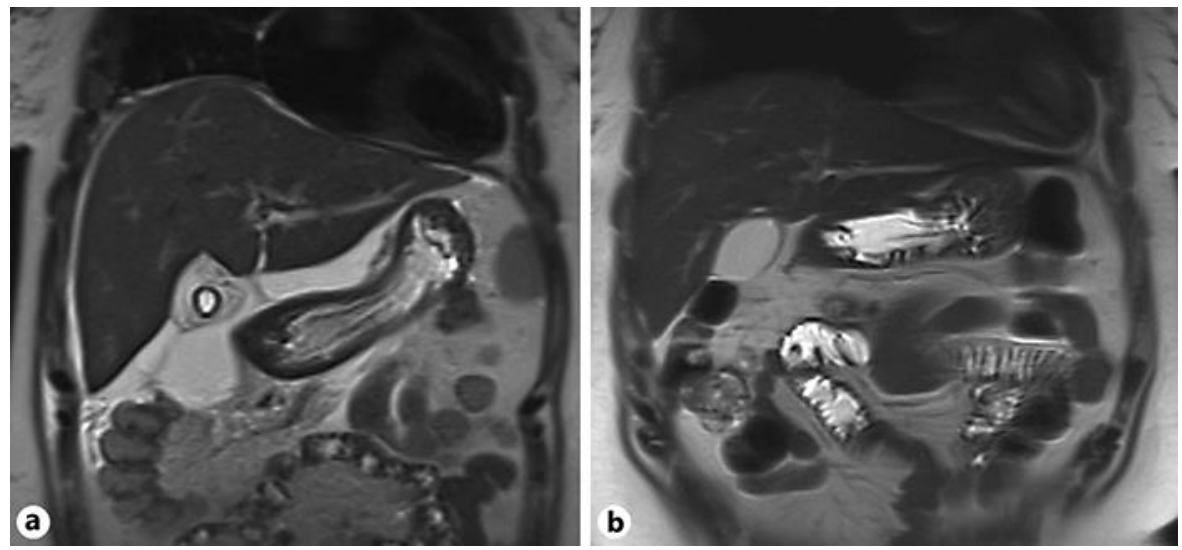

Fig. 1. Coronal T2-weighted magnetic resonance images showing a subhepatic fluid collection (a) which disappeared after drainage (b).

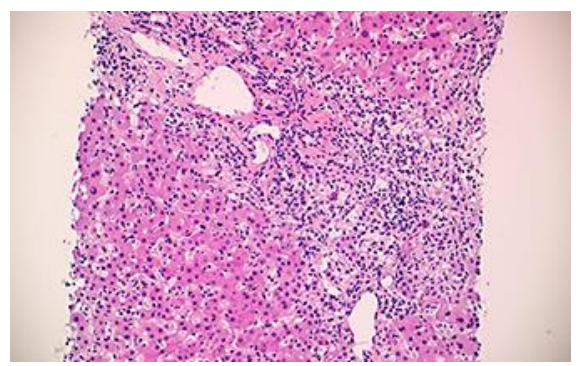

Fig. 2. Liver biopsy showing portal and lobular inflammation. HE, $\times 10$.

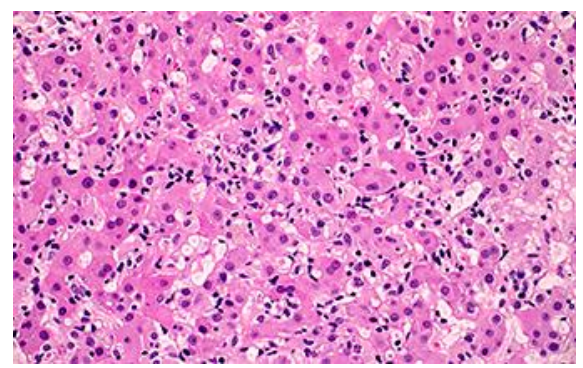

Fig. 3. Lobular inflammation composed of a mixture of lymphocytes, neutrophils, and eosinophils. HE, $\times 20$. 


\section{Case Reports in Gastroenterology}

Case Rep Gastroenterol 2021;15:115-122 (c) 2021 The Author(s). Published by S. Karger AG, Basel www.karger.com/crg

Elfert et al.: Hepatitis E Viral Association with Autoimmune Hepatitis: A Viral Trigger or Cross-Reactivity

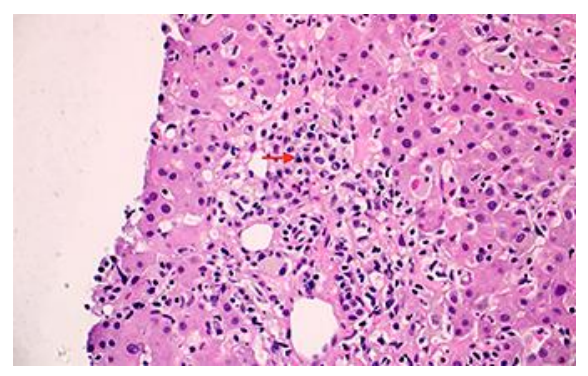

Fig. 4. High-power view of a portal tract with prominent plasma cells (red arrow). HE, $\times 20$.

Table 1. Laboratory findings

\begin{tabular}{lccccc}
\hline Laboratory tests & Day 1 & After 6 weeks & $\begin{array}{l}\text { Relapse } \\
\text { (after 3 months) }\end{array}$ & $\begin{array}{l}\text { 2 weeks } \\
\text { after relapse }\end{array}$ & Normal values \\
\hline ALT & $1,938 \mathrm{IU} / \mathrm{L}$ & $16.7 \mathrm{IU} / \mathrm{L}$ & $1,015 \mathrm{IU} / \mathrm{L}$ & $435 \mathrm{IU} / \mathrm{L}$ & $0-30 \mathrm{IU} / \mathrm{L}$ \\
AST & $1,485 \mathrm{IU} / \mathrm{L}$ & $18 \mathrm{IU} / \mathrm{L}$ & $876 \mathrm{IU} / \mathrm{L}$ & $226 \mathrm{IU} / \mathrm{L}$ & $0-31 \mathrm{IU} / \mathrm{L}$ \\
ALP & $277 \mathrm{IU} / \mathrm{L}$ & $38 \mathrm{IU} / \mathrm{L}$ & $217 \mathrm{IU} / \mathrm{L}$ & $171 \mathrm{IU} / \mathrm{L}$ & $45-129 \mathrm{IU} / \mathrm{L}$ \\
Bilirubin direct & $131 \mu \mathrm{mol} / \mathrm{L}$ & - & $36 \mu \mathrm{mol} / \mathrm{L}$ & - & $0-3 \mu \mathrm{mol} / \mathrm{L}$ \\
Bilirubin total & $153 \mu \mathrm{mol} / \mathrm{L}$ & $9.2 \mu \mathrm{mol} / \mathrm{L}$ & $45 \mu \mathrm{mol} / \mathrm{L}$ & $18 \mu \mathrm{mol} / \mathrm{L}$ & $3.5-24 \mu \mathrm{mol} / \mathrm{L}$ \\
INR & 1.3 & 1.1 & 1.1 & - & $0.8-1.1$ \\
\hline
\end{tabular}

